\title{
John Lindley (1799-1865)
}

\author{
David R. Hershey \\ Department of Horticulture, University of Maryland, College Park, MD 20742-5611
}

Lindley, one of the most remarkable horticulturists of the 19th century, was born on 5 Feb. 1799 at Catton, near Norwich, England. His father was a skillful but financially unsuccessful nurseryman. Lindley, an enthusiastic and successful student, was unable to go to college because of his family's financial situation, but his astounding ability for hard work enabled him to become one of the most productive plant scientists of his time. At age 16, Lindley went to Belgium as a seedman's representative, because his father lacked the money to buy him an officer's commission in the army. He worked with his father for a few years upon his return and became acquainted with botanist William Hooker.

Lindley demonstrated his capacity for sustained work by translating the French book Analyse du Fruit into English in one sitting of three days and two nights, despite blindness in one eye. His translation, Observations on the Structure of Fruits, was published in 1819. Lindley hoped to become a plant collector to Sumatra, and as preparation for the rigors of the trip, he slept on the bare floor.

Lindley had several careers, most of them simultaneously. He was a prominent member of the London Horticultural Society for 40 years, serving as its secretary from 1858 until his death; the first professor of botany at the Univ. of London, a position he held for 40 years; editor of the Botanical Register for 18 years and the influential Gardener's Chronicle, a publication he cofounded with Sir Joseph Paxton, for 25 years; and professor of botany and director of the Physic Garden for the Society of Apothecaries for 18 years.

In addition to his official duties, Lindley played a major role in saving Kew Gardens from being closed by- the government as a budget-cutting measure. His work led to conversion of the gardens to a public institution for horticultural display, research, and education. He was frequently consulted by the British government on matters ranging from the Irish potato famine to the vegetation of Ascension Island to fraud in horticulture. In 1830 he organized the first exhibition of flowers and fruits in England for the London Horticultural Society, the forerunner of today's Chelsea flower show. He was a juror of food products for the Great Exhibition of 1851 and superintended the horticultural exhibits of the Great International Exhibition of 1862. He successfully crusaded to repeal the glass tax, enabling wider use of greenhouses.

Received for publication 12 June 1992.

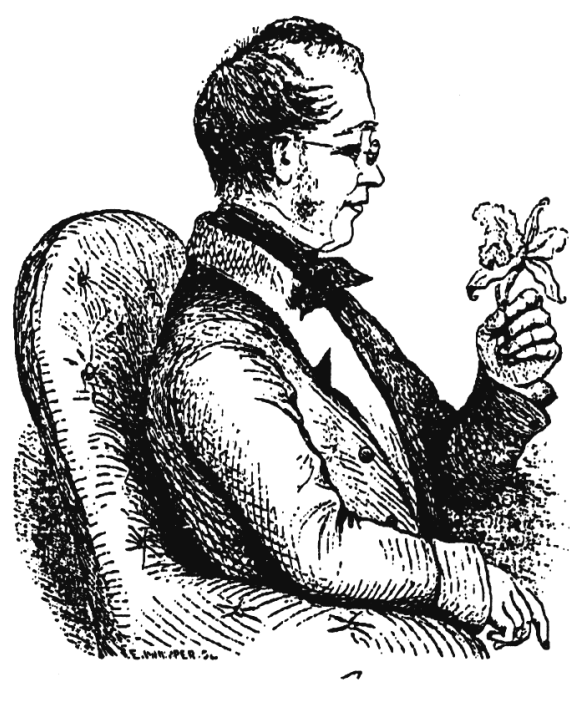

Lindley was a prolific writer and editor, with a bibliography of more than 230 technical and popular articles and books. In 1820 Lindley published Rosarum Monographia, followed in 1821 by Digitalium Monographia. He next edited William Cattley 's Collectanea Botanica. These works, along with his numerous articles in the Botanical Register, quickly gave Lindley an international reputation. His book, The Theory of Horticulture (1840) and its revisions, is considered the first modem book on horticultural science and is applicable to horticulture today. Lindley describes many "recent" innovations, including the use of bottom heat and nontraditional plant containers to prevent root circling or what Lindley termed "corkscrew roots" (Fig. 1). He begins the chapter on potting with: "When a plant is forced to grow in a ... garden pot, its condition is exceedingly different from that to which it would be naturally exposed. The roots, instead of having the power of spreading constantly outwards, and away from their original starting point, are constrained to grow back upon themselves; the supply of food is comparatively uncertain, and they are usually exposed to fluctuations of temperature and moisture unknown in a natural condition."

Lindley's pioneering works on orchid taxonomy earned him the title "father of modern orchidology." His books included Genera and Species of Orchidaceous Plants (1830-40) and Folia Orchidacea (1852-59). His botanical texts promoted the natural system of plant classification. He named innumerable new species discovered by plant explorers and started the practice of ending plant family names in "aceae." He guided plant collectors with his 1822 article "Instructions for Packing Living Plants in Foreign Countries," which was replaced only by Ward's invention of the Wardian case or terrarium in 1840.

Lindley was elected a Fellow of the Royal Society in 1828 and received their Royal Medal in 1857 for raising horticulture "from the condition of an empirical art to that of a developed science." In 1832 the Univ. of Munich granted him an honorary $\mathrm{PhD}$. Overwork associated with the 1862 exhibition caused Lindley's health to decline. He died on 1 Nov. 1865. His private library formed the Lindley library of the Royal Horticultural Society, London. His orchid collection was housed at the Kew herbarium and his general herbarium at the Univ. of Cambridge.

Despite his many accomplishments in and contributions to the science of horticulture, Lindley 's pioneering books are virtually never cited by today's horticultural textbooks. Perhaps, his inductioninto the ASHS Horticultural Hall of Fame will help contemporary textbook authors rediscover John Lindley and introduce him to today's students of horticulture.

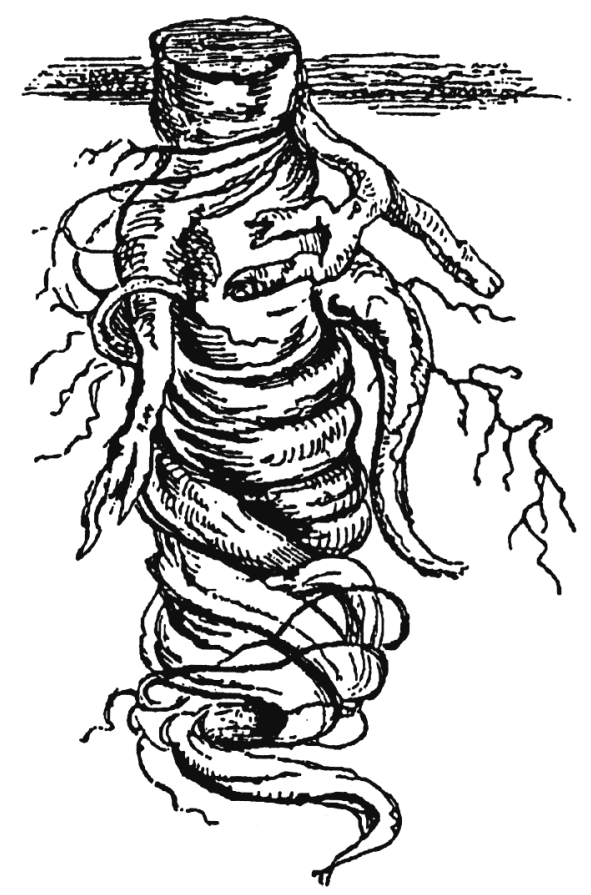

Fig. 1. Twisted or corkscrew root of Pinus laricio grown in a pot [from The Theory and Practice of Horticulture (1855)]. 


\section{References}

Earl of Morton. 1965. John Lindley. J. Royal Hort. Soc. 90:457-462.

Encyclopedia Britannica. 1981. Lindley, John. Encyclopedia Britannica Micropaedia. 6:236.

Gardener, J. 1965. John Lindley. Gardeners' Chron. 158:406,409,430,434,451,457,476,481,502, 507,526 .

Gardeners' Chronicle. 1865. The late Dr. Lindley (obituary). Gardeners' Chron. p. 105-1059, 1082-1083.

Green, J.R. 1914. John Lindley and the vegetable kingdom, p. 336-353. In: J.R. Green (ed.). A history of botany in the United Kingdom from the earliest time to the end of the 19th century. E.P. Dutton, New York.
Keeble, F. 1913. John Lindley, p. 162-177. In: F.W. Oliver (ed.). Makers of British botany. Cambridge University Press, London.

Lemmon, K. 1968. The golden age of plant hunters. Phoenix House, London.

Lindley, J. 1831. Introduction, p. v-xxvii. In: G Lindley. A guide to the orchard and kitchen garden. Longman, Brown, Green \& Longmans, London.

Lindley, J. 1855. The theory and practiceof horticulture; or an attempt to explain the chief operations of gardening upon physiological grounds. Longman, Brown, Green \& Longmans, London.

Mea, A. 1967. The Hookers of Kew. Michael Joseph, London.

Reeve, L.A. 1866. Portraits of men of eminence in literature, science and art. vol. 4. Alfred William Bennett, London.

Reinikka, M.A. 1964. John Lindley-Father of modern orchidology. Amer. Orchid Soc. Bul. 33:564-568.

Steam, W.T. 1965. The self-taught botanists who saved the Kew Botanic Garden. Taxon 14:293298.

Stearn, W.T. 1973. Lindley, John, p. 371-373. In C.C. Gillispie (ed.). Dictionary of scientific biography. vol. 8. Scribner's, New York.

Stearn, W.T. 1986. Botanical Latin. 3rd ed.,revised. David \& Charles, London. 